\title{
The evaluation of human papillomavirus and p53 gene mutation in benign and malignant conjunctiva and eyelid lesions
}

\author{
Reszec Joanna ${ }^{1}$, Zalewska Renata ${ }^{2}$, Pepiński Witold ${ }^{3}$, Skawronska Małgorzata ${ }^{3}$, \\ Piotr Bernaczyk ${ }^{1}$, Lech Chyczewski ${ }^{1}$
}

\author{
${ }^{1}$ Departament of Medical Pathomorphology, Medical University of Bialystok, Poland \\ ${ }^{2}$ Department of Ophthalmology, Medical University of Bialystok, Poland \\ ${ }^{3}$ Department of Forensic Medicine, Medical University of Bialystok, Poland
}

\begin{abstract}
Papillomas and squamous cell carcinomas are the most common conjunctival and eyelid lesions. The etiology is still unclear and recently human papillomavirus infection and $p 53$ gene mutation have been taken into consideration. The aim of our study was the evaluation of HPV DNA presence and $p 53$ gene mutation in 45 benign and 38 malignant squamous lesions of the conjunctiva and eyelid. For HPV detection PCR-RFLP and immunohistochemical reaction were used; for $p 53$ gene mutation PCR-SSCP was used. Only $8.8 \%$ papillomas, 9.1\% squamous cell cancers and 3.7\% basal cell cancers (using PCR-RFLP method) and $26.6 \%$ papillomas, $7.4 \%$ squamous cell cancers and $9.1 \%$ basal cell cancers (using immunohistochemical reaction) were HPV positive. p53 gene mutation was evaluated in $24.4 \%$ papillomas, $54.5 \%$ squamous cell cancers and $22.2 \%$ basal cell cancers; most commonly in 6 and 7 exon. Human papillomavirus infection, opposite to $p 53$ gene mutation, is not a significant etiological factor of the benign and malignant conjunctival and eyelid lesions development.
\end{abstract}

Key words: Human Papillomavirus, p53 gene mutation, immunohistochemistry, PCR

\section{Introduction}

The affinity of human papillomavirus (HPV) to squamous epithelium has been well documented, especially associated witharrising benign, precancerous lesions and invasive squamous cell carcinoma of the cervix, oral, anogenital region, carcinomas of the head and neck and upper aerodigestive tract [1]. The most common lesions of the conjunctical and eyelid epithelium are papillomas and squamous cell cancers with the etiology associated with external irritants such as UV irradiation, wind, and dust. Patients, usually men older than 50 years, frequently reported a history of a previous pinguecula, pterygium, or actinic keratosis of the conjunctiva $[2,3]$. However DNA for HPV types 6 and 11 is consistently demonstrable in benign papillomas of the conjunctiva. Types 6 and 11 are probably responsible for the majority of the benign papillomas

Correspondence: J. Reszec, Dept. of Medical Pathomorphology, Medical University of Bialystok,

Waszyngtona Str. 13, 15-269 Bialystok, Poland;

e-mail: joasia@umwb.edu.pl of human conjunctiva. Only a few studies on the association of conjunctival carcinomas with HPV have been reported, and the results are inconsistent [3-5].

P53 tumor suppressor acts as transcriptional activator, controlling the expression of a variety of genes important in cell cycle regulation and apoptosis. Approximately half of all cases of human cancer maybe attributed to a defective $p 53$ protein. Most of these are caused by missence mutations in the $p 53$ gene, changing one amino acid in the protein to another. This may alter the binding of the protein to DNA or to the transcription factors, corrupting the signal from p53 to the cell [6-8].

The aim of the study was to evaluate the DNA presence of human papillomavirus using two different methods as well as the $p 53$ gene mutation in benign and malignant lesions of the eyelid and conjunctival squamous epithelium.

\section{Materials and methods}

A series of 83 lesions of the conjunctival and eyelid epithelium was estimated: 45 squamous cell papillomas, including 7 cases 


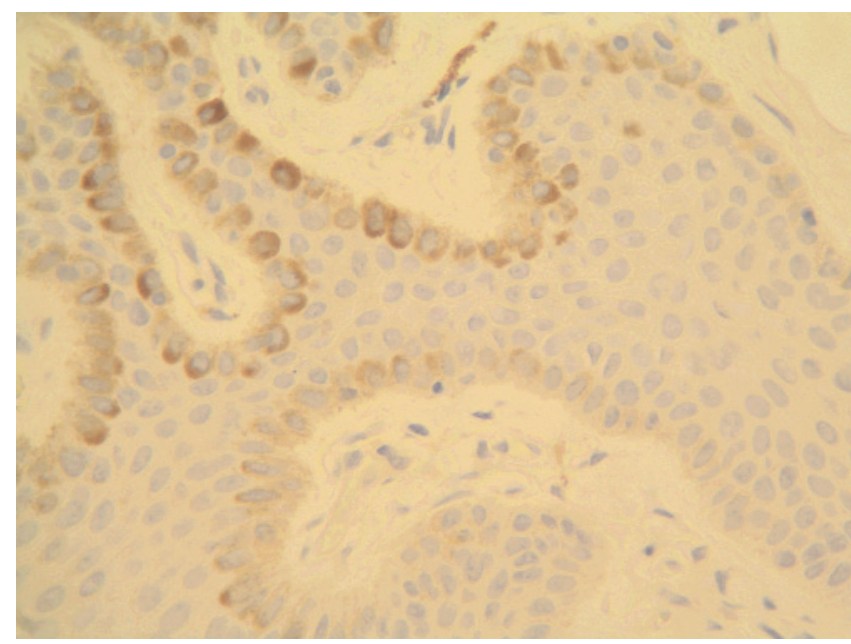

Fig. 1. Squamous cell papilloma of the conjunctiva. Cytoplasmatic immunohistochemical reaction with HPV antibodies (Dako) observed mostly in the basal layer of the epithelium. Original magnification $\times 200$.

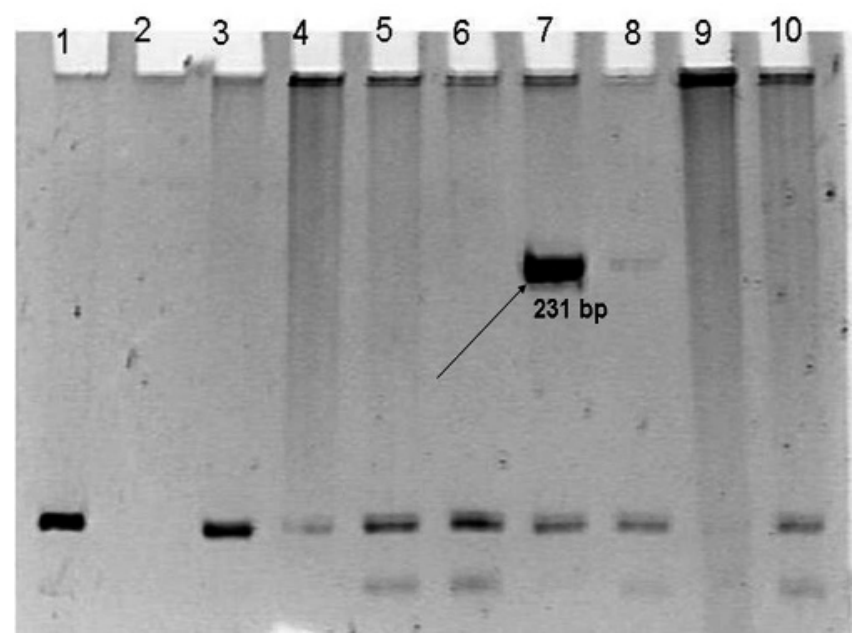

Fig. 3. PCR-RFLP reaction products for malignant type $(16,18)$ human papillomaviruses (line 7 and 8 ) used primers $\mathrm{pU}-1 \mathrm{M} / \mathrm{pU}$ 2R (231-268 pb).

with koilocytic dysplasia, 11 squamous cell cancers and 27 basal cell cancers. The patients' age ranged from 18 to 94 years in papilloma group, and from 42 to 87 years in cancer group. $92.1 \%$ of the cancers and $73.3 \%$ of papillomas were located on the eyelid. Formalin fixed, paraffin embedded sections of each lesion were stained with haematoxylin and eosin and examined to confirm the diagnosis. The immunohistochemical reaction was performed to present the DNA of human papilomavirus. Rabbit antibovine papillomavirus antibody was purchased from Dako. Immunohistochemical staining was performed by the avidinbiotin complex method. The sections were deparaffinised, endogenous peroxidase was blocked by incubation of the slides for 10 minutes in $1 \% \mathrm{NaIO}_{4}$, and, after being washed, the slides were incubated with primary antibodies (dilution 1:100). The slides were then exposed to a biotinylated anti-rabbit immunoglobulin antiserum (dilution 1:50), avidin (dilution 1:100) and biotinylated horseradish peroxidase complex. The peroxidase reaction was performed by incubating the slides in $0.005 \% \mathrm{H} 2 \mathrm{O} 2$ and $0.02 \% 33^{\prime}$ diaminobenzidine tetrahydrochloride for 10 minutes. The specimens of cervix with high dysplasia

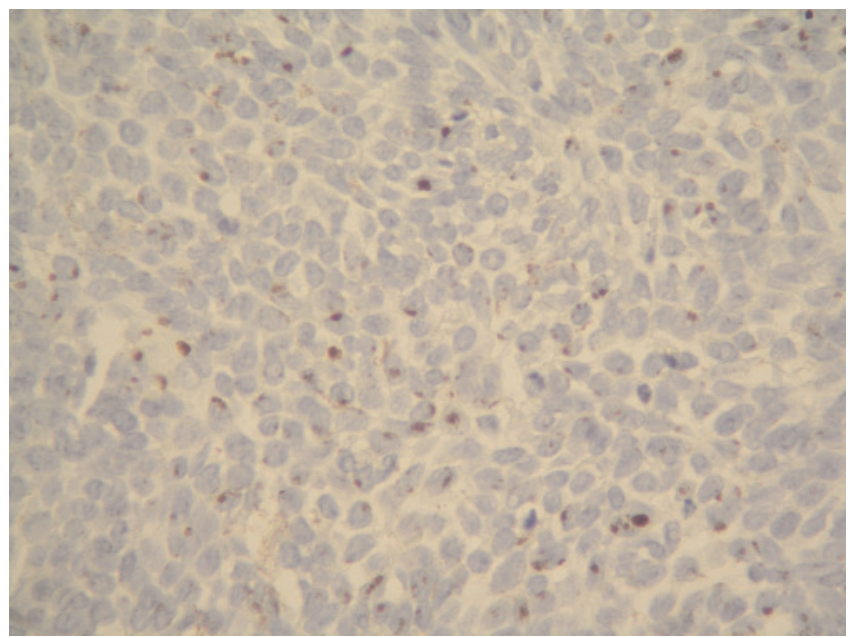

Fig. 2. Squamous cell carcinoma of the conjunctiva. Immunohistochemical reaction with HPV antibodies observed in the nuclei of the neoplastic cells. Original magnification $\times 200$.

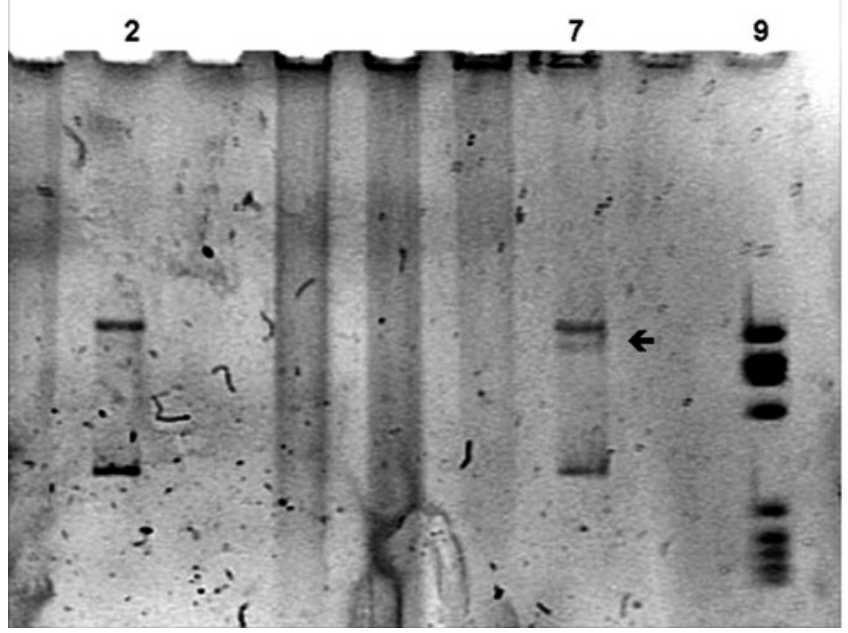

Fig. 4. PCR-SSCP reaction products- p53 mutation in 5 exon (line 2,7). Line 9 pBR322 III Hae.

(CIN 3) were used as a positive control, and phosphate buffered saline instead of primary antibody as the negative control.

To estimate the DNA presence of huaman papillomavirus the polymerase chain reaction was performed. DNA was isolated from the paraffin- embedded tissues with GenElute Mammalian Genomic DNA Kit (Sigma). The PCR-RFLP reaction was performed with the proper primers pairs to benign and malignant types of human papillomaviruses (TaKaRa). The products of PCR-RFLP reactions were visualized on the $6 \%$ polyacrylamid gels.

The $p 53$ gene mutation was evaluated by using PCR- SSCP method. Exons 5-8 of the p53 gene were PCR-amplified independently using the oligonucleotide primers shown in Table 1.

40 PCR cycles comprising denaturation, annealing and elongation at $96^{\circ} \mathrm{C}$ for $30 \mathrm{sec}, 57.5^{\circ} \mathrm{C}(\mathrm{e}-5), 58.2^{\circ} \mathrm{C}(\mathrm{e}-6), 57.4^{\circ} \mathrm{C}(\mathrm{e}-7)$, $53.05^{\circ} \mathrm{C}(\mathrm{e}-8)$, and $72^{\circ} \mathrm{C}$ for $30 \mathrm{sec}$ were carried out. The PCR products were denaturated with the loading dye buffer at $95^{\circ} \mathrm{C}$ for 10 minutes and applied to $6 \%$ non-denaturating polyacrylamide (acrylamide-bisacrylamide 49:1) gel containing 5\% glycerol and electrophoresed in cooling chamber in $20^{\circ} \mathrm{C}$ at $30 \mathrm{~mA}$ through 30 hours. 
Table 1. Sequence of oligonucleotide primers for $\mathrm{p} 53$ gene mutation.

\begin{tabular}{|c|c|}
\hline Sequence & Lixon \\
\hline $5^{\prime}-\wedge G G G G T C \wedge G C G G C \wedge \wedge G C \wedge G \wedge-3^{\prime}$ & 7 \\
\hline 5'-TTGGG $\wedge G T \wedge G \wedge T G G \wedge G C C T-3{ }^{\prime}$ & 8 \\
\hline $5^{\prime}-\wedge \mathrm{GGC} \wedge \mathrm{T} \wedge \wedge \mathrm{CTGC} \wedge \mathrm{CCCTTGG-3'}$ & 8 \\
\hline 5'GTTTCTTTGCTGCCGTGTTC-3' & 5 \\
\hline $5^{\prime}-\wedge$ GGCCTGGGG $\triangle$ CCCTGGGC $\Lambda-3$ ' & 5 \\
\hline 5'-TGGl'TGCCCAGGGICCCCAG-3' & 6 \\
\hline 5'-GGAGGGCCACIGACAACCA-3' & 6 \\
\hline 5'-ClTGCCACAGGICTCCCCAA-3' & 7 \\
\hline
\end{tabular}

\section{Results}

The products of PCR-RFLP were obtained only with using the primers pairs to malignant types of HPV (Fig. 3).

HPV DNA was detected in 4 out of 45 papillomas $(8.8 \%), 1$ out of 11 squamous cell cancers $(9.1 \%)$, and 1 out of 27 basal cell cancers $(3.7 \%)$.

Human papillomavirus positive immunohistochemical reaction was observed in 12 out of 45 papillomas (26.6\%) (Fig 1), 2 out of 27 basal cancers $(7.4 \%)$ and 1 out of 11 squamous cell cancers (9.1\%) (Fig. 2).

All PCR-RFLP positive lesions showed also HPVpositive immunostaining. All 7 cases with koilocytic dysplasia was HPV positive using immunohistochemocal reaction however only 2 cases using PCRRFLP method.

P53 gene mutation was observed in 12 malignant lesions including 6 out of 11 squamous cell cancers $(54.5 \%)$, mostly estimated as G1 and G2 and in 6 out of 27 basal cell cancers $(22.2 \%)$. The most frequent mutation was occurred in exons 6 and 7 (Fig 4).

In papillomas group $p 53$ gene mutation was present in 11 out of 45 cases $(24.4 \%)$ also most commonly in exons 6 and 7 .

In 5 out of 7 human papillomavirus- positive lesions $p 53$ gene mutation was also observed.

\section{Discussion}

The recent data indicate the HPV infection as a predictive factor of the various lesion developments, including benign and malignant lesions of the conjunctiva and eyelid. However the studies performed between 1986 and 2008 brought very various results of the association between the type of the lesion and the presence of HPV, as well as the differences of the using methods. Naghashfar et al. [3] showed HPV in 1 out of 3 squamous cell papillomas, McDonell et al. [1] all in 15 out of 23 papillomas, Mincione et al. [4] al in
2 out of 4 papillomas, Saegusa et al. [13] in 75\% squamous cell papillomas. Nakamura et al. [5] estimated 17 patients with neoplastic lesions of the conjunctiva. HPV particles were observed in 8 lesions including 4 papillomas, 3 papillomas with koilocytic dysplasia and in 1 in carcinoma in situ using immunohistochemical reaction. Using in situ hybridization HPV DNA was observed in 5 cases, in 4 cases HPV benign type and 4 HPV malignant type using PCR-RFLP reaction.

Our study proves PCR-RFLP reaction more sensitive comparing to immunohistochemical reaction to HPV estimation. Similar to Matsumoto et al. [6], Toth at al. [8] and Eng et al. [9] in the recent studies the HPV presence in squamous carcinomas ranged from 86\% (Ateenyi-Agaba et al. [10]) to 0\% (Eng et al. [9], Newton et al. [12], and Tulvatana et al. [11]). In our study a very low percentage of HPV-positive cases might indicate other than viral etiology of benign and malignant lesions of the conjunctiva and eyelid. However the various percentages of HPV positive lesions in the recent data might be also associated with various types of methods, in PCR-RFLP technique with different types of primers, magnesium concentrations as well as the used isolation techniques. It also might be associated with geographical differentiations between etiological factors such as life style, environmental factors and genetic predispositions.

In our present study we also evaluated the $p 53$ gene mutation, which seemed to be the most common event in the squamous cancer development. Among all of the conjunctiva and eyelid lesions the most important evidence, which might lead to malignancy, occurred $p 53$ mutation. Although in papilloma group p53 mutation might be also an important cofactor especially in progression to dysplasia and cancer. In the recent data only Ateenyi-Agaba et al. [10] observed $p 53$ mutation in $52 \%$ cases of squamous cell cancers. Also difficult is to find evaluations associated with $p 53$ mutation in squamous cell papillomas, therefore our study gives an important view to conjunctival and eyelid squamous epithelium lesions development.

\section{References}

[ 1] Mcdonell JM, Mcdonell P, Sun YY. HPV DNA in tissues and ocular surface swabs of patients with conjunctival epithelial neoplasia. IOVS. 1992;33:184-189.

[2] Newton R. A review of etiology of squamous cell carcinoma of the conjunctiva. Br J Cancer. 1996;74:1511-1513.

[3] Naghashfar Z, Mcdonell PJ, Mcdonell JM, Green WR, Shah KV. Genital tract papillomavirus type 6 in recurrent conjunctival papilloma. Arch Ophthalmol. 1986;104:1814-1815.

[4] Mincione GP, Taddei GL, Wolovsky M, Calzolari A, Mincione F. Detection of HPV DNA type 6/11 in a conjunctival papilloma by in situ hybridisation with biotynylated probes. Pathologica. 1992;84:483-488.

[5] Nakamura Y, Kameyama K, Mukai M. Detection of human papillomavirus infection in squamous tumours of the conjunctiva and lacrimal sac by immunohistochemistry, in situ 
hybridisation, and polymerase chain reaction. Br J Ophthalmol. 1997;81;308-313.

[ 6] Matsumoto CS, Nakatsuka K, Imaizumi M. Squamous cell carcinoma of the palpebral conjunctiva. Br J Ophtalmology. 1997:801:802.

[ 7] Goodsell DS. The molecular perspective: p53 tumor suppressor. The Oncologist. 1999;4:138-139.

[ 8] Toth J, Karcioglu ZA, Moshfeghi AA, Issa TM, Al-Maani JR, Patel KV. The relationship between HPV and p53 gene in conjunctival squamous cell carcinoma. Cornea. 2000;19:159162.

[9] Eng HL, Lin TM, Chen SY, Wu SM, Chen WC. Failure to detect human papillomavirus DNA in malignant epithelial neoplasms of conjunctiva by polymerase chain reaction. Am J Clin Pathol. 2002;117:429-436.

[10] Atenyi-Agaba C, Dai M, Le Calvez F, Katongole-Mbidde E, Smet A, Tommasino M, Franceschi S, Hainaut P, Weiderpass E. TP53 mutations in squamous-cell carcinomas of the con- junctiva: evidence for UV-induced mutagenesis. Mutagenesis. 2004;19:399-401.

[11] Tulvatana W, Bhattarakosol P, Sansopha L, Sipiyarak W, Kowitdamrong E, Paisuntornsug T, Karnasawai S. Risk factors for conjunctival squamous cell neoplasia: a matched case-control study. Br J Ophthalmol. 2003;87:396-398.

[12] Newton R, Ziegler J, Ateenyi-Agaba C, Bousarghin L, Casabonne D, Beral V, Mbidde E, Carpenter L, Reeves G, Parkin DM, Wabinga H, Mbulaiteye S, Jaffe H, Bourboulia D, Boshoff C, Touze' A, Coursaget P. Uganda Kaposi's Sarcoma Study Group. The epidemiology of conjunctival squamous cell carcinoma in Uganda. Br J Cancer. 2002;87:301-308.

[13] Saegusa M, Takano Y, Hashimura M, Okayasu I, Shiga J. HPV type 16 in conjunctival and junctional papilloma, dysplasia, and squamous cell carcinoma. J Clin Pathol. 1995;48:1106-1110.

Submitted: 2 June, 2010 Accepted after reviews: 19 September, 2010 